\title{
Aspirația de corp străin la copil - încă o provocare în pediatrie?
}

\author{
Cristina Iolanda Vivisenco ${ }^{1,2}$, Andra Farcaşi ${ }^{1}$, Adelaida Iorgulescu ${ }^{3}$, \\ Ioana Adelina Mertic ${ }^{3}$ \\ ${ }^{1}$ Departamentul Toxicologie, Spitalul Clinic de Urgenţă pentru Copii \\ "Grigore Alexandrescu“, Bucureşti, România \\ 2Departamentul Pediatrie, Universitatea de Medicină şi Farmacie „Carol Davila“, Bucureşti, România \\ ${ }^{3}$ Departamentul ORL, Spitalul Clinic de Urgenţă pentru Copii \\ „Grigore Alexandrescu“, Bucureşti, România
}

\begin{abstract}
REZUMAT
Aspiraţia de corpi străini în arborele traheobronşic reprezintă o urgenţă diagnostică şi terapeutică în practica specialiştilor pediatri şi ORL-işti. Întârzierea diagnosticului şi, implicit, a extragerii bronhoscopice a corpului străin poate conduce la o serie de complicaţii, unele chiar cu prognostic vital. În lucrarea de faţă, autorii prezintă din experienţa personală două cazuri pediatrice de corpi străini traheobronşici diagnosticaţi şi trataţi la intervale diferite de timp faţă de momentul aspiraţiei.
\end{abstract}

Cuvinte cheie: corp străin traheobroşic, bronhoscopie, copil

\section{INTRODUCERE}

Aspiraţia de corpi străini în arborele traheobronşic de către copii rămâne şi la ora actuală o patologie des întâlnită în serviciile de pediatrie şi ORL, caracterizată printr-un spectru larg de forme de prezentare, de la simptome minime, ce pot trece neobservate, până la insuficienţă respiratorie de diferite grade şi chiar deces prin sufocare (1).

La ora actuală, în România nu există o evidenţă la nivel naţional a cazurilor de aspiraţie de corpi străini în arborele traheobronşic. Datele publicate în literatură provin din cercetările centrelor naţionale pe loturi limitate de pacienţi. În Statele Unite ale Americii se estimează anual în jur de 2.000 de cazuri pediatrice internate cu acest diagnostic. Rata de mortalitate intraspitalicească asociată acestor cazuri este de $1,8 \%$, iar injuria anoxică cerebrală este comunicată în 2,2\% dintre cazuri (2).

Majoritatea cazurilor de corpi străini traheobronşici sunt raportate în primii 3 ani de viaţă, cu o incidenţă maximă în grupa de vârstă 1-2 ani şi o predominanţă clară a sexului masculin (3). Există o serie de factori favorizanţi pentru aspiraţie precum tendinţa specifică vârstei de a explora mediul înconjurător introducând orice obiect în gură, diametrul mic al căilor aeriene ce predispune la obstrucţie, dar şi lipsa molarilor ce împiedică mestecarea completă a alimentelor (4).

În lucrarea de faţă prezentăm două cazuri de corpi străini traheobronşici la copii mici, diferite prin tabloul clinic şi anamnestic, diagnosticate şi tratate în echipă de către specialistul pediatru şi ORL-ist.

\section{Cazul 1}

Copil de sex feminin, în vârstă de 2 ani şi 2 luni, s-a internat de urgenţă pentru febră, dispnee mixtă şi suspiciune de aspiraţie de corp străin. Din antecedentele personale patologice am reţinut că pacienta este cunoscută cu hiperreactivitate a căilor respiratorii în context infecţios încă de la vârsta de sugar, fiind expusă la intercurenţele respiratorii ale sorei mai mari, ce frecventează grădiniţa. Antecedentele heredocolaterale sunt nesemnificative. 
Debutul simptomatologiei actuale a fost cu 24 de ore anterior internării, cu obstrucţie nazală şi febră pentru care a primit tratament cu antitermice. $\mathrm{Cu} 15$ ore anterior internării, în timp ce mânca alune, copilul a prezentat un acces brusc de tuse spastică, urmat de dispnee. Examenul clinic efectuat la internare a evidenţiat un copil cu stare generală mediocră, febril $(38,8$ grade C) şi tahicardic (alura ventriculară $=150$ bătăi pe minut), cu rinoree şi faringe intens hiperemic. La examinarea aparatului respirator am constatat tuse spastică, dispnee mixtă, wheezing, polipnee (frecvenţa respiratorie $=40$ respiraţii pe minut), murmur vezicular prezent bilateral, diminuat la nivelul hemitoracelui drept bazal.

Investigaţiile paraclinice efectuate în urgenţă au obiectivat leucocitoză $(19.000 / \mathrm{mmc})$ cu neutrofilie (74\%) şi sindrom biologic inflamator (proteină C reactivă $=10,9 \mathrm{mg} / \mathrm{dl}$ ). Radiografia pulmonară a evidenţiat interstiţiu pulmonar accentuat bilateral şi discretă hipertransparenţă pulmonară la nivelul unghiului cardio-diafragmatic drept (figura 1). Corelând imaginea radiologică cu tabloul stetacustic pulmonar şi anamneza sugestivă pentru un eventual sindrom de aspiraţie, am decis efectuarea în urgenţă a bronhoscopiei sub anestezie generală. S-au extras două fragmente mari de alună de la nivelul bronhiei primitive drepte (figura 2).

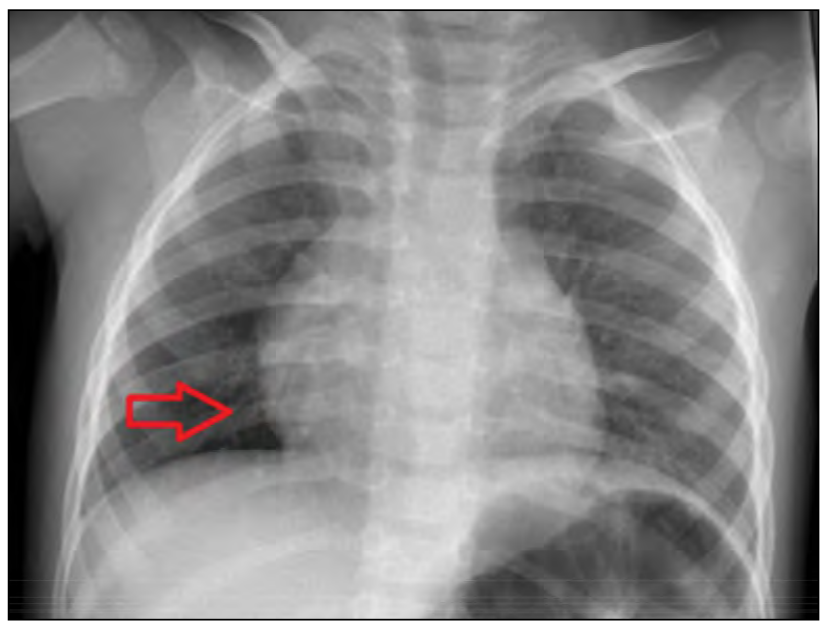

FIGURA 1. Discretă hipertransparență pulmonară la nivelul unghiului cardio-diafragmatic drept

Pacienta a primit antibioterapie sistemică, corticoterapie inhalatorie şi simptomatice. Evoluţia clinică şi paraclinică după extragerea corpului străin a fost rapid favorabilă. Copilul s-a menţinut afebril şi fără sindrom funcţional respirator după intervenţia bronhoscopică. A persistat tusea timp de 7 zile, iar la examenul clinic s-au mai decelat raluri bronşice şi expir uşor prelungit timp de 48 de ore. Din cauza acestor simptome, am repetat examenul radiologic pulmonar după 5 zile de la bronhoscopie. Acesta a arătat doar desen interstiţial încă accentuat bilateral, fără tulburări de ventilaţie. Au fost repetate şi probele de laborator, care au arătat un număr normal de leucocite, fără sindrom inflamator. Am considerat persistenţa simptomelor respiratorii pe parcursul mai multor zile ca fiind cauzată de suprapunerea aspiraţiei de corp străin cu o intercurenţă respiratorie, la un copil cu istoric de hiperreactivitate a căilor respiratorii.

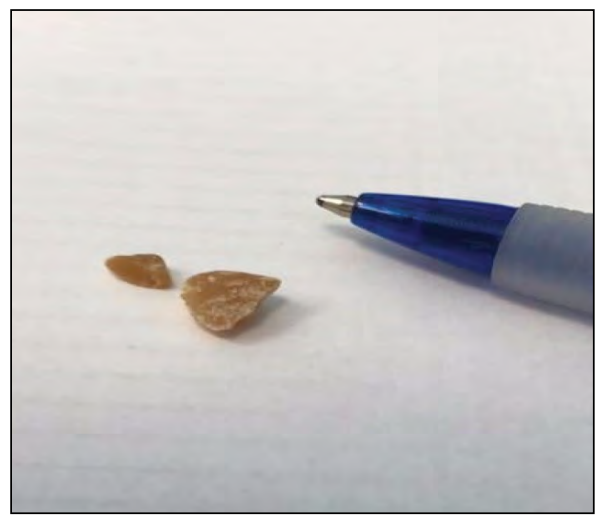

FIGURA 2. Fragmente de alună extrase cu bronhoscopul rigid de la nivelul bronhiei primitive drepte

Pacienta a fost externată după 5 zile şi urmărită timp de 12 luni, perioadă în care nu a prezentat nicio complicaţie secundară aspiraţiei de corp străin.

\section{Cazul 2}

Copil de sex feminin, în vârstă de 3 ani s-a internat pentru tuse spastică cvasipermanentă şi wheezing persistent. Din antecedentele heredocolaterale reţinem că mama are rinită alergică, iar din cele personale patologice reţinem că pacienta a prezentat repetate viroze respiratorii.

Debutul simptomatologiei a fost cu o lună anterior internării cu tuse seacă, wheezing şi un croşet

febril (38 grade C). A fost internată două zile într-o altă unitate medicală cu diagnosticul de laringotraheobronşită acută, pentru care a primit tratament cu antibiotic per os, bronhodilatatoare şi antiinflamatorii inhalator. Deoarece simptomatologia a persistat, a efectuat alte două consulturi de pediatrie, respectiv pneumologie pediatrică, stabilindu-se diagnosticul de wheezing persistent indus viral. A primit tratament de fond timp de o lună cu inhibitor de leucotriene, precum şi bronhodilatatoare şi antiinflamatorii administrate inhalator.

Examenul clinic la internare a evidenţiat un copil cu stare generală mediocră, afebril şi cu facies suferind. La examinarea aparatului respirator am constatat tuse spastică cvasipermanentă, epuizantă, wheezing, iar auscultator murmurul vezicular era 
diminuat la nivelul hemitoracelui stâng, cu raluri bronşice prezente la acest nivel.

Analizând radiografia pulmonară iniţială, efectuată în urmă cu o lună, la debutul simptomatologiei, am constatat hipertransparenţă la nivelul hemitoracelui stâng şi împingerea mediastinului de partea contralaterală (figura 3a). În buletinul de interpretare iniţial acest aspect era interpretat ca opacifiere a hemitoracelui drept, ceea ce a condus probabil la interpretarea episodului ca fiind infecţie acută de căi respiratorii inferioare, la momentul respectiv. Am repetat radiografia pulmonară la prezentarea în clinica noastră şi am constatat menţinerea hipertransparenţei la nivelul hemitoracelui stâng, mai puţin evidentă faţă de imaginea iniţială, aspect atenuat prin suprapunerea interstiţiului pulmonar accentuat bilateral (figura 3b). Având in vedere aspectul sugestiv al radiografiilor pentru aspiraţie de corp străin, am reluat anamneza şi părinţii au relatat că, în ziua în care a debutat simptomatologia, copilul ,s-a înecat cu o alună“, susţinând că au menţionat acest aspect şi la prezentările anterioare. Ţinând cont de datele anamnestice sugestive şi de modificările radiologice, am efectuat bronhoscopie sub anestezie generală. S-au extras fragmente vechi de alună de la nivelul bronhiei primitive stângi, care erau inclavate în ţesut de granulaţie (figura 4).

Pacienta a primit tratament cu antibioterapie şi corticoterapie sistemică. Evoluţia după extragerea corpului străin a fost rapid favorabilă, cu dispariţia completă a tusei. La examenul clinic s-au mai dece- lat rare raluri bronşice la nivel interscapulovertebral stâng în primele 24 de ore.

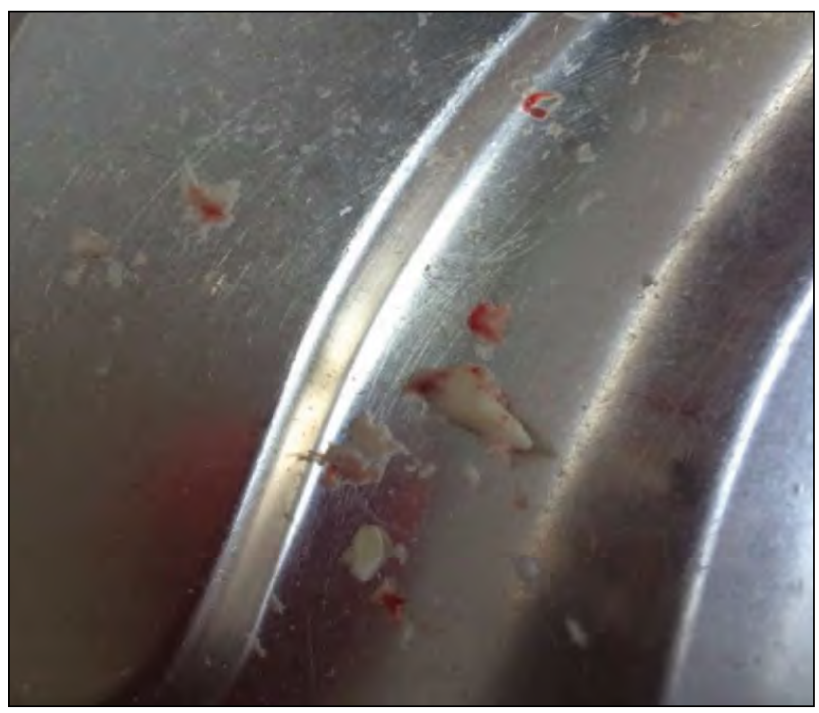

FIGURA 4. Fragmente vechi de alună inclavate în țesut de granulație, extrase bronhoscopic de la nivelul bronhiei primitive stângi.

Pacienta a fost externată după 3 zile, cu recomandări de tratament antibiotic şi corticoterapie inhalatorie la domiciliu. A fost monitorizată timp de 24 luni. În primul an, a prezentat două episoade de infecţii acute de căi respiratorii inferioare cu localizarea focarului stetacustic şi radiologic la nivelul hemitoracelui stâng. În al doilea an, nu a mai prezentat niciun episod similar. Am interpretat infecţiile recidivante ca fiind favorizate de modificările structurale de la nivelul arborelui respirator,

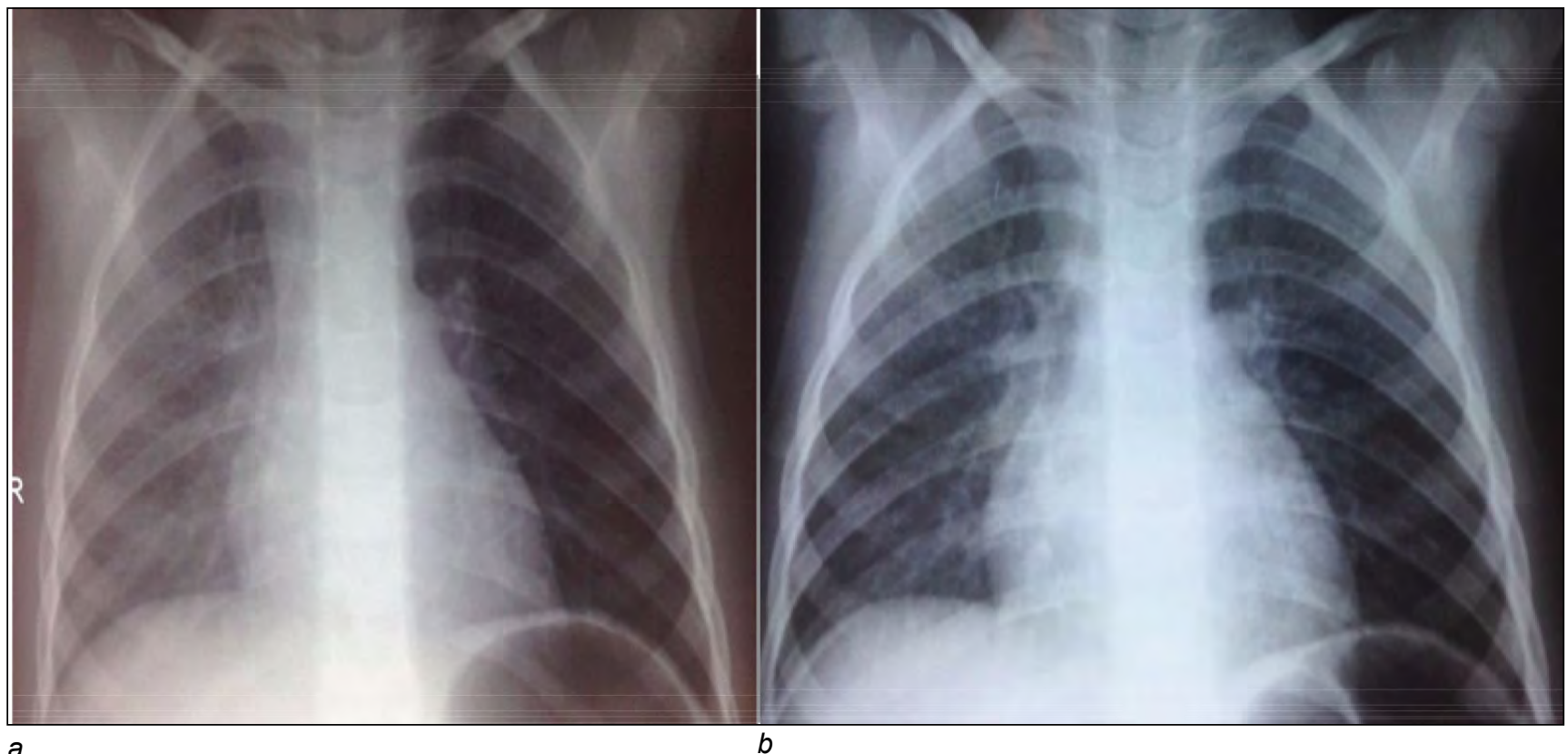

FIGURA 3. a: Radiografie pulmonară efectuată la momentul aspirației de corp străin; b: Radiografia pulmonară efectuată după o lună de la debutul simptomatologiei 
apărute în urma diagnosticului întârziat de aspiraţie de corp străin.

\section{DISCUṬII}

În ambele cazuri prezentate, corpii străini traheobronşici au fost de natură organică, vegetală. Acesta este tipul cel mai des întâlnit în practica medicală, aşa cum reiese şi din studiul lui Mallick, efectuat pe 158 de copii internaţi cu suspiciunea de aspiraţie de corp străin, în $80 \%$ dintre cazuri fiind vorba de un corp străin vegetal (alune sau seminţe de pepene) (5). Similar, Ciftci a analizat 663 de cazuri pediatrice, identificând corpi străini organici în $75 \%$ dintre cazuri (seminţe de floarea-soarelui, alune, arahide) (6).

Anamneza bine condusă este esenţială în această patologie, istoricul de sindrom de penetraţie (acces brusc de tuse, sufocare, cianoză) fiind elementul cheie care ghidează diagnosticul pozitiv. Un studiu efectuat de Fontoba şi colaboratorii pe 100 de pacienţi a evidenţiat faptul că prezenţa sindromului de penetraţie este parametrul clinic cu cea mai înaltă sensibilitate (97\%) şi specificitate (63\%). Comparativ cu acesta, celelalte simptome și aspectul radiologic, deşi au sensibilitate înaltă $(88 \%$, respectiv $85 \%$ ), au specificitate joasă ( $9 \%$ ) (7). Există însă numeroase cazuri în care absenţa martorilor în momentul producerii evenimentului nu permite identificarea anamnestică a sindromului de penetraţie, ceea ce poate întârzia stabilirea diagnosticului. În ambele cazuri relatate, sindromul de penetraţie a fost prezent, doar că, în cea de-a doua situaţie, simptomele respiratorii iniţiale nu au fost interpretate corect, ceea ce a dus la întârzierea diagnosticului pozitiv. Un studiul efectuat de Steen şi Zimmermann pe 94 de cazuri pediatrice de corpi străini traheobronşici menţionează că $24 \%$ dintre pacienţi au fost trataţi iniţial pe baza unui alt diagnostic, iar în 30\% dintre cazuri, copiii au fost internaţi la mai mult de 3 zile de la momentul aspiraţiei (8). Astfel, aspiraţia de corp străin la copil poate fi diagnosticată eronat ca fiind o exacerbare a astmului bronşic, pneumonie acută, laringită acută subglotică sau wheezing recurent (9). Această situaţie de diagnostic iniţial eronat a fost întâlnită şi în cel de-al doilea caz prezentat, care era tratat pentru wheezing persistent indus viral.

Aspiraţia de corp străin se poate transforma întro patologie severă dacă rămâne nediagnosticată o perioada mai lungă de timp. Întârzierea diagnosticului şi, implicit, a tratamentului adecvat pot duce la complicaţii precum pneumonie, infecţii recidivante, atelectazie pulmonară sau bronşiectazii. Un studiu efectuat de Karakoc şi colaboratorii, ce a inclus 174 de copii diagnosticaţi cu aspiraţie de corp străi,n a pus în evidență un risc de $60 \%$ de apariţie a complicaţiilor în rândul celor diagnosticaţi la mai mult de 30 de zile după producerea aspiraţiei corpului străin. În $25 \%$ dintre cazurile diagnosticate la mai mult de 30 de zile de la momentul aspiraţiei, bronşiectaziile au fost o complicaţie majoră, 3 dintre pacienţi necesitând în final lobectomie (10). Rezultate similare au fost evidenţiate şi de Shlizerman, care a demonstrat în cazul a 136 de copii cu aspiraţie de corp străin o rată dublă de apariţie a complicaţiilor la pacienţii ce au ajuns la spital la mai mult de 2 zile de la momentul aspiraţiei. De asemenea, s-a constatat o rată dublă de apariţie a complicaţiilor la pacienţii ce au efectuat bronhoscopie la mai mult de 24 de ore de la sosirea la spital, faţă de cei ce au efectuat bronhoscopie în primele 24 de ore (11). În al doilea caz prezentat, întârzierea diagnosticului a condus la infecţii pulmonare recurente în aceeaşi arie în care a fost localizat corpul străin.

În momentul examinării clinice, copilul se poate găsi într-un interval asimptomatic sau poate prezenta un anumit tablou clinic din multitudinea de aspecte patologice pe care le implică prezenţa unui corp străin în arborele traheobronşic. Tabloul clinic poate pune în evidenţă tuse, wheezing, stridor, sindrom funcţional respirator, hipersonoritate sau matitate pulmonară, diminuarea murmurului vezicular, raluri sibilante şi/sau subcrepitante sau suflu tubar (12). Radiografia pulmonară ajută la stabilirea diagnosticului, atunci când demonstrează zone de emfizem cu sau fără împingerea mediastinului spre plămânul contralateral sau zone de atelectazie. În plus, poate evidenţia complicaţii, precum pneumonie cu sau fără pleurezie, bronhopneumonie, abces pulmonar, pneumotorax sau pneumomediastin. Un aspect radiologic normal sau nesugestiv de aspiraţie de corp străin nu exclude însă diagnosticul. Zerella şi colaboratorii au studiat 265 de cazuri de copii cu aspiraţie de corp străin dovedită, dintre care 110 cazuri $(41,5 \%)$ au avut radiografii cu aspect normal (13).

Efectuarea bronhoscopiei sub anestezie generală rămâne cea mai bună metodă de diagnostic şi tratament. Examinarea arborelui traheobronşic cu ajutorul bronhoscopului rigid ar trebui efectuată în toate cazurile de suspiciune de aspiraţie de corp străin la vârstă pediatrică (14). Complicaţiile bronhoscopiei, deşi rare, pot fi severe: pneumotorax, hemoragie, stop cardiorespirator (12). În studiul lui Ciftci, îndepărtarea prin bronhoscopie a corpilor străini a fost realizată cu succes în $99 \%$ dintre ca- 
zuri. A fost necesară o a doua şi o a treia bronhoscopie într-un număr mic de cazuri $(3,2 \%$ şi, respectiv, $0,8 \%$ dintre pacienţi) (6).

Investigarea prin tomografie computerizată este o opţiune de diagnostic atunci când suspiciunea de corp străin traheobronşic rămâne ridicată, în ciuda unei bronhoscopii negative sau în cazurile în care se suspicionează corp străin rezidual după extragerea bronhoscopică $(12,15)$.

\section{CONCLUZII}

Gradul înalt de suspiciune clinică şi anamneza bine condusă sunt esenţiale în diagnosticarea pre- coce a corpilor străini traheobronşici. Întârzierea diagnosticului va conduce la tratamente inadecvate, internări repetate sau prelungirea spitalizării şi chiar apariţia complicaţiilor imediate şi la distanţă. Bronhoscopia rămâne metoda de elecţie pentru diagnosticarea, dar şi tratarea corpilor străini traheobronşici.

\section{Menţiune}

Primii doi autori au contribuit în mod egal la realizarea articolului.

Conflict of interest: none declared Financial support: none declared

\section{BIBLIOGRAFIE}

1. Naragund AI, Mudhol RS, Harugop AS. Tracheo-bronchial foreign body aspiration in children: A one year descriptive study. Indian J Otolaryngol Head Neck Surg. 2011; 66(Suppl 1): p. 180-5.

2. Kim IA, Shapiro N, Bhattacharyya N. The national cost burden of bronchial foreign body aspiration in children. Laryngoscope. 2015; 125(5): p. 1221-4.

3. Eren $S$, Balci AE, Dikici B. Foreign body aspiration in children: Experience of 1160 cases. Ann Trop Paediatr. 2003; 23(1): p. 31-7.

4. Committee on Injury, Violence, and Poison Prevention. Prevention of choking among children. Pediatrics. 2010; 125(3): p. 601-7.

5. Mallick MS. Tracheobronchial foreign body aspiration in children: A continuing diagnostic challenge. Afr J Paediatr Surg. 2014; 11(3): p. 225-8.

6. Ciftci AO, Bingöl-Koloğlu M, Senocak ME. Bronchoscopy for evaluation of foreign body aspiration in children. J Pediatr Surg. 2003; 38(8): p. 1170-6.

7. Fontoba JEB, Gutierrez C, Lluna J. Bronchial foreign body: Should bronchoscopy be performed in all patients with a choking crisis? Pediatr Surg Int. 1997; 12(2/3): p. 118-20.

8. Steen KH, Zimmermann T. Tracheobronchial aspiration of foreign bodies in children: a study of 94 cases. Laryngoscope. 1990; 100(5): p. 525-30.

9. Mantor PC, Tuggle DW, Tunell WP. An appropriate negative bronchoscopy rate in suspected foreign body aspiration. Am J Surg. 1989; 158(6): p. 622-4.

10. Karakoç $F$, Karadağ B, Akbenlioğlu C. Foreign body aspiration: What is the outcome? Pediatr Pulmonol. 2002; 34(1): p. 30-6.

11. Shlizerman L, Mazzawi S, Rakover Y. Foreign body aspiration in children: The effects of delayed diagnosis. Am J Otolaryngol. 2010; 31(5): p. 320-4.

12. Hitter $A$, Hullo $E$, Durand $C$. Diagnostic value of various investigations in children with suspected foreign body aspiration: Review. Eur Ann Otorhinolaryngol Head Neck Dis. 2011; 128(5): p. 248-52.

13. Zerella JT, Dimler M, McGill LC. Foreign body aspiration in children: Value of radiography and complications of bronchoscopy. J Pediatr Surg. 1998; 33(11): p. 1651-4.

14. Acharya K. Rigid Bronchoscopy in Airway Foreign Bodies: Value of the Clinical and Radiological Signs. Int Arch Otorhinolaryngol. 2016; 20(3): p. 196-201.

15. Shin SM, Kim WS, Cheon JE. CT in Children with Suspected Residual Foreign Body in Airway after Bronchoscopy. AJR Am J Roentgenol. 2009; 192(6): p. 1744-51. 